Natural Hazards and Earth System Sciences (2003) 3: 423-433

(C) European Geosciences Union 2003

Natural Hazards and Earth System Sciences

\title{
Kinematics of the 1991 Randa rockslides (Valais, Switzerland)
}

\author{
M. Sartori ${ }^{1,2}$, F. Baillifard ${ }^{1,3}$, M. Jaboyedoff ${ }^{1,4}$, and J.-D. Rouiller ${ }^{1}$ \\ ${ }^{1}$ CREALP - Research Centre on Alpine Environment, Industrie 45, 1951 Sion, Switzerland \\ ${ }^{2}$ Department of Geology and Paleontology, University of Geneva, Maraîchers 13, 1211 Genève 4, Switzerland \\ ${ }^{3}$ Institute of Geology and Paleontology, University of Lausanne, BFSH2, 1015 Lausanne, Switzerland \\ ${ }^{4}$ Quanterra, Chemin Tour-Grise 28, 1007 Lausanne, Switzerland
}

Received: 16 January 2003 - Accepted: 3 February 2003

\begin{abstract}
About 22 mio $^{3}$ of rock fell from a cliff near the village of Randa (10 km north of Zermatt, Switzerland) on 18 April 1991. A second retrogressive rockslide of about 7 mio m$^{3}$ followed on 9 May 1991. At present, a rock mass situated above the scarp is still slowly moving toward the valley, involving several mio $\mathrm{m}^{3}$ of rock.

A kinematic approach to study of this well-documented rockslide was made "a posteriori" in order to identify the parameters relevant to the detection of such failures involving large volumes of rock. A 3-D model of the pre-rockslide geometry is presented, and is used to interpret the geostructural, hydrogeological, and chronological data.
\end{abstract}

The steepness of the cliff, the massive lithology (mainly orthogneiss), the location on a topographic ridge outcropping at the confluence between a glacial cirque and the main valley, and the existence of previous events of instability were the pre-existing field conditions that affected the stability of the area. The structural cause of instability was a $30^{\circ}$ dipping, more than 500-m-long, persistent fault, which cut the base of the rock face. Together with a steeply dipping set of persistent joints, this basal discontinuity delimited a 20mio- $\mathrm{m}^{3}$ rock block, with a potential sliding direction approximately parallel to the axis of the valley. To the North, the fractures delimiting the unstable mass were less persistent and separated by rock bridges; this rock volume acted as key block.

This topographic and structural configuration was freed from glacier support about 15000 years BP. The various mechanisms of degradation that led to the final loss of equilibrium required various amounts of time. During the lateand post-glacial periods, seismic activity and weathering of the orthogneiss along the fissure network due to infiltration of meteoric water, joined to reduce the mechanical resistance of the sliding surfaces and the rocks bridges. In addition, crystallisation of clay minerals due to mineralogical alteration of the fault gouge accumulated along the sliding sur-

Correspondence to: F. Baillifard

(francois.baillifard@crealp.ch) face, reducing its angle of internal friction, and sealing the surface against water circulation. Once this basal fracture began to act as an aquiclude, the seasonal increase of the hydraulic head in the fissures promoted hydraulic fracturing on the highly stressed edges of the key block. Acceleration of this mechanical degradation occurred during the 20-year period before the 1991 rockslides, giving rise to an increasing rockfall activity, that constituted a forewarning sign. The final triggering event corresponded to a snow-melt period with high water table, leading to fracturation around the key block.

On 18 April 1991, the key block finally failed, allowing subsidiary orthogneiss blocks to slide. They fell in turn over a period of several hours. The 9 May 1991, rockslide was the first of a series of expected future retrogressive reequilibrium stages of the very fractured and decompressed paragneisses, which lie on the orthogneiss base cut by the 18 April event.

\section{Introduction}

\subsection{The 1991 Randa rockslides}

The steep western mountainside of the Mattertal (Switzerland), downstream from the village of Randa ( $10 \mathrm{~km}$ north of Zermatt), was the site on 18 April and 9 May 1991, of a twostage rockslide with a total volume of $30 \mathrm{mio} \mathrm{m}^{3}$ (Ischi et al., 1991; Noverraz and Bonnard, 1991; von Bidder, 1991; Pirocchi, 1992; Rouiller, 1992; Götz and Zimmermann, 1993; Schindler et al., 1993; Naturforschende Gesellschaft Oberwallis, 1995) (Fig. 1). Fortunately, there were no casualties, and no rock-avalanche deposits were produced because of the breaking up of the rock face into several individual blocks over a period of several hours (Schindler et al., 1993). On the contrary, a steep cone of debris was formed. The road and railway connecting Zermatt to the Rhône valley were interrupted. The debris cone dammed the Mattervispa River, creating a lake that flooded part of the settlement of Randa. To prevent the formation of a similar lake in the future, a 


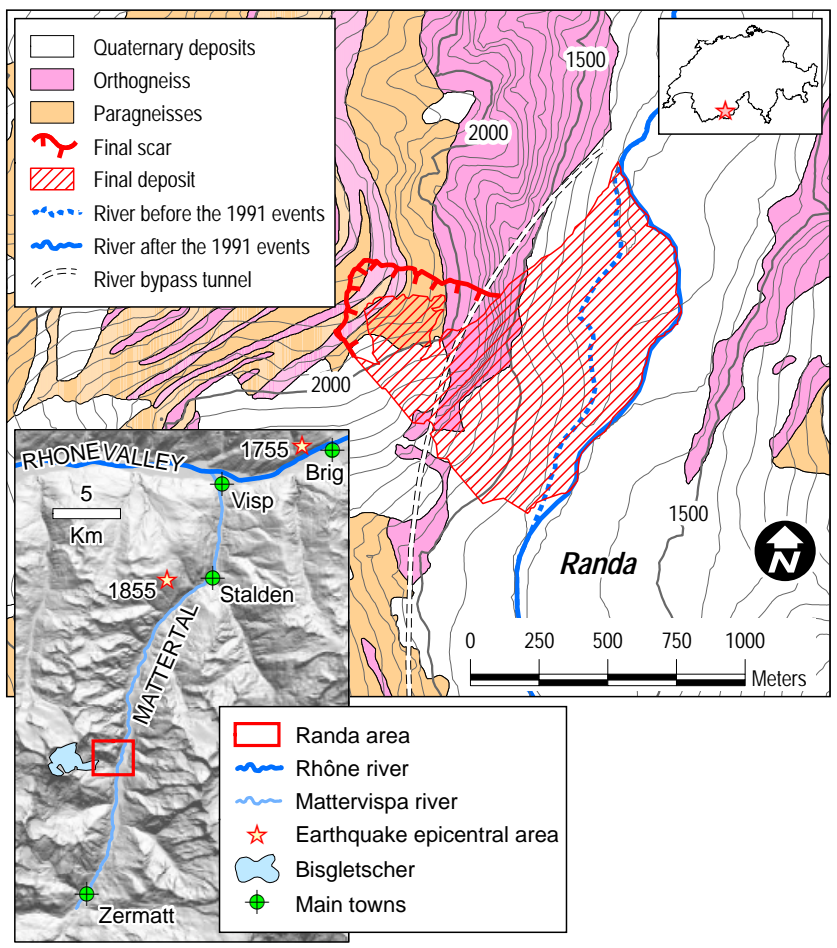

Fig. 1. Hillshade of the Mattertal (data: SWISSTOPO) and epicentral location of the 1755 and 1855 earthquakes (data: Ecos, Swiss Seismological Service), location of the Randa rockslides and simplified geological map (after Bearth, 1964).

3770-m-long bypass tunnel was bored through the western valley wall. This tunnel allows geotechnical observation of the bedrock, including 3-dimensional extrapolation of the positions of the fractures (Girod, 1999). Movements along the present scarp have been measured since 1991; they indicate the potential for new rockslide activity involving a few mio $\mathrm{m}^{3}$ of material.

The geological and geotechnical investigations made during and after the 1991 events mainly involved management of the crisis, i.e. volume estimations, analysis of the monitoring results (Ischi et al., 1991; Pirocchi, 1992; Rouiller, 1992; Götz and Zimmermann, 1993), and small-scale geomechanical analysis of the 9th May rockslide (Wagner, 1991). A synthesis of data may be found in Schindler et al. (1993), in which the effects of alteration and triggering factors have been analyzed. Mineralogical alteration processes affecting the rock mass were investigated by Girod (1999). A 2-D numerical rock-stability model was developed by Ferrero et al. (1996).

\section{2 "A posteriori" analysis}

Analyzing recent landslides is very useful in understanding the main parameters to be considered for the detection of further slope instability. The Randa rockslides, for which terrestrial and aerial pictures, precise topographic maps, and digi- tal terrain models (DTM) are available, provide an excellent opportunity for such an "a posteriori" analysis.

During this project, we made in situ observations, and interpreted photographic and topographic materials with the object of developing a 3-D geometrical model of the rock face as it was before the 1991 events. We then tried to understand the chronology of the pre-1991 destabilizing events in terms of the kinematic processes that led to the 1991 rockslides. To explain the "20th century slope failures", the history of the Randa mountain slope must be considered since late- or post-glacial times. New insights on the pre-existing field conditions, the geometry of the unstable mass, the triggering mechanisms, and the kinematics of the Randa rockslides are presented.

\section{Pre-existing field conditions}

\subsection{Steep slopes}

Randa's physical location is exceptional, in a valley that ranks among the deepest erosional incisions in the Alps. The village lies at an elevation of $1400 \mathrm{~m}$ on the thalweg of a valley that is topped by two summits (Weisshorn, Dom) $11 \mathrm{~km}$ apart, with summit elevations of $4500 \mathrm{~m}$. From over $10 \mathrm{~km}$ distance downstream away from Randa, the western wall of this typical glacial valley ranges in steepness from $60^{\circ}$ to vertical cliffs, 400 to $600 \mathrm{~m}$ high. This pronounced U-shaped morphology corresponds to the steep outcrops of an especially competent lithology: the Randa orthogneiss (Bearth, 1964). Because the dominant regional tectonic feature consists of a steep $30^{\circ}$ axial trend westward, the eastern wall of the valley presents a dip-slope morphology, and is thus less steep and more uniform than the western wall.

\subsection{Confluence of two glacial valleys}

Several perched glacial cirques notch the western wall of the Mattertal. Generally, rock outcrops located downstream of the confluence between the tributaries and the main valley present two characteristics: (1) these mountain flanks underwent especially high confining pressures due to the joining of two glaciers during the glacial periods, as well as high decompression processes during late- to post-glacial periods, and (2) the range of slope orientations is wider in such outcrops than on a single valley's wall, increasing the number of potential sliding surfaces on pre-existing discontinuities. The Randa unstable area is located on a ridge formed by the intersection of the Mattertal main valley and the Bisgletscher glacial cirque (Fig. 1).

\subsection{Competent lithology}

The lithology controls the steepness of the western wall of the Mattertal (Fig. 1): the Randa orthogneiss is a Permian porphyritic granite intruded as a pseudo-laccolith within the Pre-Permian paragneisses and the Permian metagreywackes of the Siviez-Mischabel nappe (Bearth, 1964; Thélin, 1987). 


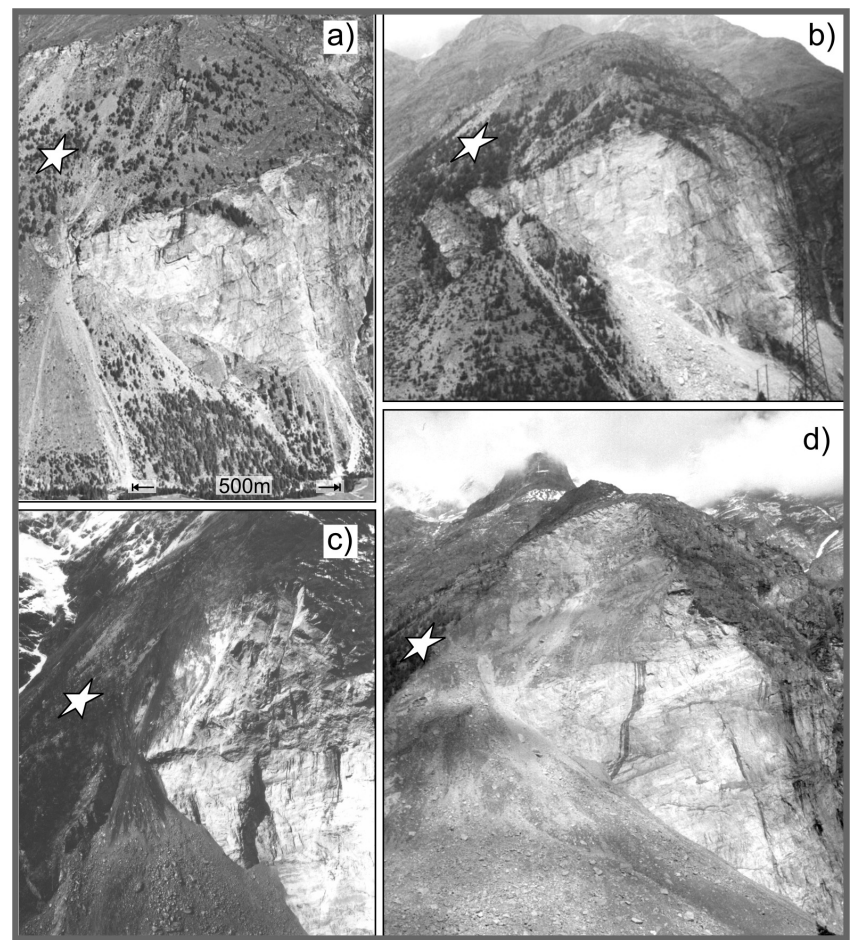

Fig. 2. Evolution of the Randa valley wall through time. The vertical cliff consists of orthogneiss, the uppermost dark slopes of paragneisses. Star: reference mark. (a) 1930 (photograph: SWISSTOPO, 1930). (b) 1984 (photograph: Swiss Army, 1984). (c) After the 18 April rockslide (photograph: Swiss Army, 1991). (d) After the 9 May rockslide (photograph: M. Sartori, 1992).

This granitic body has been affected by Alpine pervasive deformation. It appears to be a huge boudin, dipping westward, apparently $1 \mathrm{~km}$ thick and $20 \mathrm{~km}$ wide. Within this competent and homogenous body, fractures related to the Alpine deformations are more persistent and more developed than within the surrounding lithologies. This can be observed at map scale (Bearth, 1964). In the cliff above the village of Randa, the massive orthogneiss is directly overlain by paragneisses with minor, up to 10-m-thick bands of micaschist and orthogneiss.

\subsection{Persistent fractures}

Identification of persistent fracture lineaments was performed on terrestrial and aerial photographs, and on DTM from before, during, and after the 1991 events (Fig. 3).

Three main steep orthogonal fracture sets (designated J2, J5 and J6) were easily detected on aerial photographs. J2 and $\mathrm{J} 6$ were better developed within the Randa orthogneiss than within the overlying paragneisses, whereas J5 occurred more frequently and had a shorter average spacing within the paragneisses than in the orthogneiss. A single steep fracture with a East-West tending strike (J6') was easily recognizable on terrestrial views: this fracture delimited the northern border of the 18 April unstable mass. Two less-steep frac-

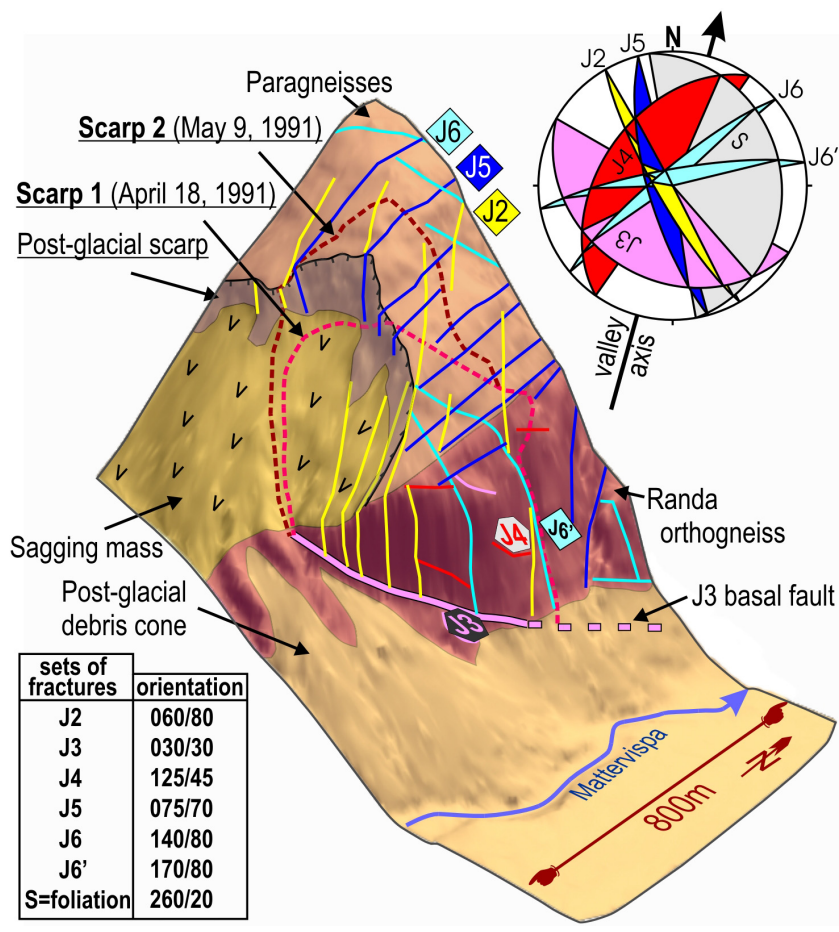

Fig. 3. Geomorphological and structural settings of the 1991 Randa rockslides and orientations of the main sets of persistent discontinuities (Schmidt-Lambert stereonet, upper hemisphere). An old rockslide scarp forms the southern flank of the ridge, partly covered by sagging material. The change in the steepness of the slope corresponds with the limit between the orthogneiss and the paragneisses. The most striking structural feature is the basal J3 fault, cutting the base of the cliff. The main persistent fractures are represented. They were used to delimit the rock blocks in the 3-D model.

ture sets $(\mathrm{J} 3, \mathrm{~J} 4)$ were more difficult to recognize on vertical views. They appeared as grassy ledges. The dip values of these fracture sets, obtained by dip-slope measurements, range from $45^{\circ}$ to $60^{\circ}$. A single $\mathrm{J} 3$ fracture was the most prominent geologic structure on the cliff before the rockslides. On Fig. 2, this fracture appears clearly as a more than 500-m-long, persistent, $30^{\circ}$ apparent-dipping discontinuity, cutting the base of the Randa orthogneiss above the top of the debris cone. The trend of the planar tectono-metamorphic fabric of the granitic body is $250 / 20$, due to two or more subparallel greenschist facies schistosities. Parallel to this foliation, regularly spaced joints have developed and form a set of persistent discontinuities ( $\mathrm{S}$ in Fig. 3). These joints possibly originated from decompression processes in response to rapid tectonic unloading.

At a smaller scale, six to ten discontinuity sets were found by statistical measurements of joints, mainly related to the mechanism of the 9 May rockslide (Wagner, 1991). Progressive opening of some of these fractures was monitored before and during the 9 May rockslide, allowing interpretation of the effective sliding surfaces and wedges (Ischi et al., 1991; Wagner, 1991).

All of these fractures were formed during late-Alpine 


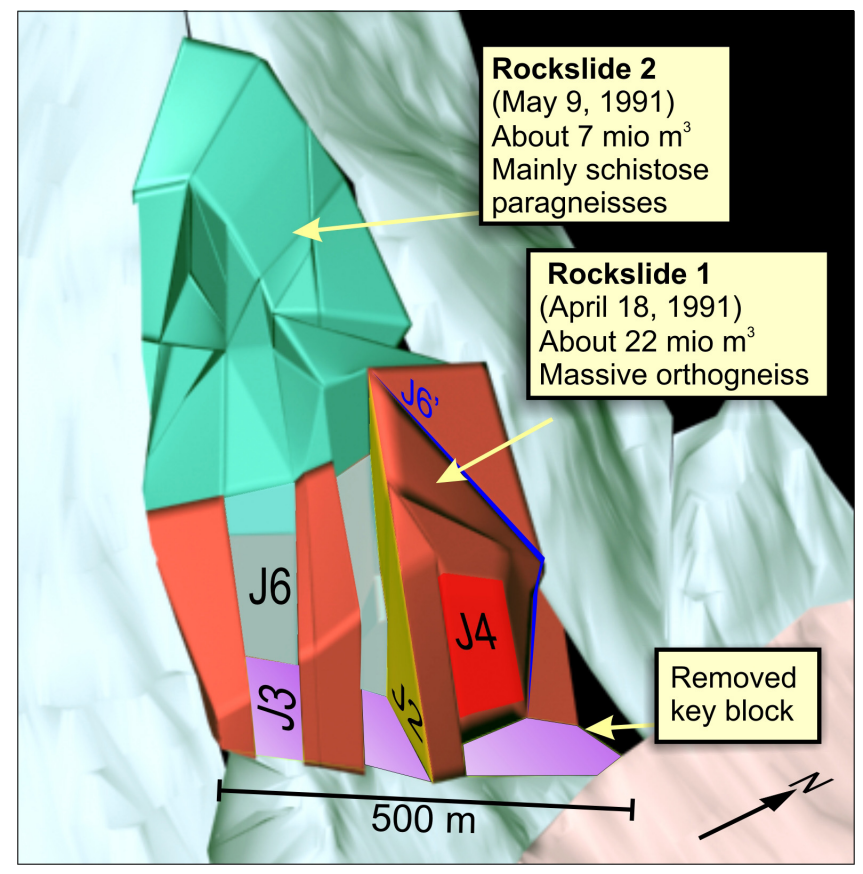

Fig. 4. 3-D geometrical model of the 18 April (red) and 9 May 1991 (turquoise blue), unstable masses. Three of the ten rock blocks forming the April failure have been removed for this diagram in order to expose the sliding surfaces (J3, violet; J4, red). The removed block at the lower right side acted as a key block. Due to the high density of fractures, the 9 May unstable mass broke into very small volumes; however, here it has been schematically divided into nine blocks.

(Neogene) brittle deformations. Post-glacial decompression processes led to the opening of these pre-existing discontinuities, and to the failure of rock bridges between some of them. In the present case, the post-glacial decompression certainly did not produce new persistent joints, as confirmed by observations made in the bypass tunnel (Girod, 1999).

\subsection{Long-term disequilibrium}

The survey of the pre-1991 morphology clearly revealed the existence of previous instabilities of unknown age. An old rockslide scarp weakened the southern flank of the paragneisses ridge (Fig. 3). The rockslide deposit from this scarp probably consists of the large debris cone extending to the foot of the cliff. This cone was at that time one of the largest dry fans of the Mattertal, with a volume estimated at 10 to 15 mio $^{3}$. The ridge area concerned by this old instability favoured infiltration of snow-melt water and therefore indirectly contributed to the destabilization process of the Randa rock face during the "20th century slope failures" (Sect. 5.2). This old rockslide scarp was cut by the 1991 rockslides.

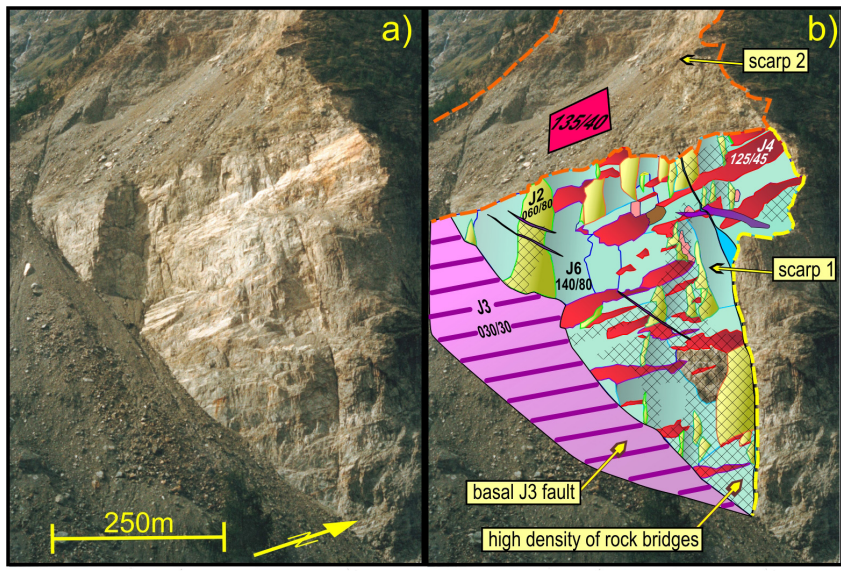

Fig. 5. (a) Lower part of the scarp of the Randa rockslides after the 18 April and 9 May 1991, events. (b) Structural interpretation of Fig. 5(a): this part of the scarp, untouched by the second stage (9 May) event, exposes the detachment (blue, J6) and sliding (red, J4) surfaces of the 18 Aprilth rockslide. The basal sliding surface (violet, J3) is hidden by the debris cone. The roughness of these surfaces, tentatively correlated with the density of fractured rock bridges, is clearly higher on the lower right (northern) side of the scarp, and highlights the key status of this rock block. The sliding surface of the second stage of the rockslide, also hidden by scree, appears in the upper part of the photograph (photograph: J.D. Rouiller, 1991).

\section{3-D geometrical model of the 1991 rockslides}

Using the most persistent discontinuities, observed and traced from the pre-rockslide topography to the successive scarps, a simplified 3-D deterministic model of the pattern of discontinuities was constructed for the entire Randa rock slope before the failure. This 3-D model assumes polyhedral geometries for the rock blocks. The coordinates of the summits of the polyhedrons were fixed, and the topology of the faces was built using the 3-DStudioMax 5.0 software (Discreet, 2002).

The 18 April 1991, rockslide (rockslide 1 in Fig. 4) has been modeled by ten blocks roughly delimited in the Randa orthogneiss with three surfaces: the basal J3 (030/30) surface, the rear near-vertical J6-J6' (155/80) composite system, and the southern J2 (060/80) lateral surface. The southern half of the rock volume is divided by persistent $\mathrm{J} 2$ discontinuities, strongly marked on the original rock face (Fig. 2 ab). Six prismatic blocks, with volumes ranging from 1 to $3 \mathrm{mio}^{3}$ are distinguished. The northern half of the rock mass is dominated by less-persistent $\mathrm{J} 4$ discontinuities, that dip southeast. Four blocks are superposed on J4 basal surfaces. The lowest (i.e. "foot") block of the northern part lays on the J3 basal fault, and hereafter will be referred to as the "key block" (Goodman and Shi, 1985).

The 9 May 1991, rockslide (rockslide 2 in Fig. 4) cut the paragneisses ridge with a complex geometry. The striking feature was a wide basal slip surface, now hidden by debris 
(Fig. 5, upper part), oriented 135/40, thus similar to the J4 discontinuity set, but probably consisting of a complex fracture relay system. An arch-shaped scarp was limited to the rear of the rock volume lying on this basal surface. Its southern side consisted mainly of a moderately dipping J2-like orientated surface. The head and the northern side of the scarp were composite surfaces due to traction on the highly fractured paragneisses. Nine blocks have been distinguished in this second-stage mass, divided by persistent joints observed on the original topography. Because of the density of fractures, the reliability of this model is less pertinent than the one of the 18 April rockslide.

This 3-D model led to the first volume estimation of the two events separately: $22.5 \mathrm{mio} \mathrm{m}^{3}$ for the 18 April event and $7 \mathrm{mio}^{3}$ for that of 9 May. Uncertainties about these volume estimates resulting from the simplified topographic surface do not exceed $10 \%$. This fully independent volume characterization can be compared to that of Ischi et al. (1991), who calculated the difference between the two DTMs (before and after the two events) that provided a total volume for both events of $27 \mathrm{mio} \mathrm{m}^{3}$. The result found by Ischi et al. could have be on the low side, because of the partial burial of the scarp beneath the debris cone.

\section{Degrading mechanisms}

Our simplified 3-D model uses fully discontinuous and free rock blocks. However this model is not accurate for the prerockslide situation, because the slope was in a relatively stable state during several thousand years before the failure. A part of the discontinuities used as boundary surfaces on the 3-D model were certainly discontinuous joints separated by cohesive rock volumes (rock bridges). This can be observed on the 18 April scarp (Fig. 5). Some parts of the surfaces were planar and smooth and corresponded to pre-existing fractures; other parts were rough and curved, probably due to the great number of fractured rock bridges.

Most of the rock bridges broke during the 18 April rockslide itself. However, some of the rock bridges should have broken before the major event, explaining the progressive deformations observed on the rock wall (see Sect. 5.2). Previous studies (Schindler et al., 1993; Ferrero et al., 1996; Girod and Thélin, 1998; Girod, 1999; Eberhardt et al., 2001) have already focused on two main degrading causes: seismicity and groundwater circulation.

\subsection{Macroseismic activity}

Previous macroseismic activity undoubtedly influenced the strength of the Randa rock slope. Indeed, the Brig-VispStalden-Randa area is exposed to the strongest regional seismic hazard in Switzerland, with a mean probability of occurrence of about one VIII to IX MSK intensity earthquake for a 1 000-year return period (Saegesser and Mayer-Rosa 1978; Wagner et al., 2000). The two latest strong earthquakes near Randa occurred in 1755 (epicentral location: Brig, $30 \mathrm{~km}$

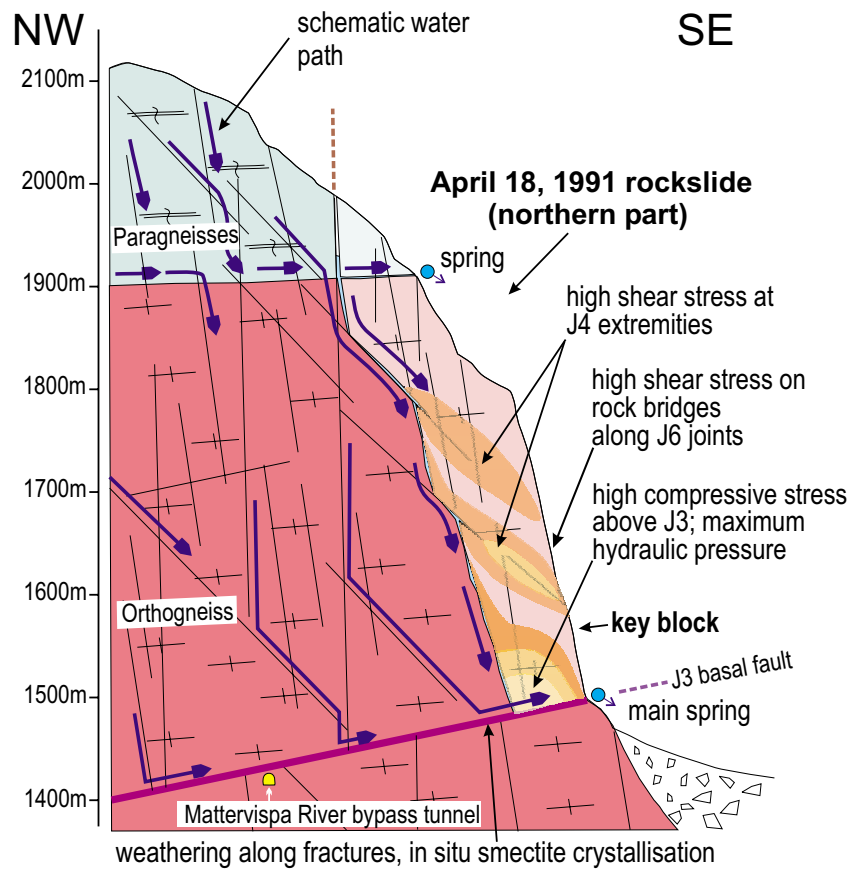

Fig. 6. Geological cross section through the northern part of the 18 April 1991, scarp with both hydrogeological and dynamic interpretations. The $\mathrm{J} 3$ fault constitutes the basal sliding surface, despite its apparent re-entrant orientation in this section. This fault, sealed with clay minerals due to weathering, acts as an aquiclude. Temporary flow utilizes the fissure network, in particular the open J2 fractures that are behind the unstable mass. The lithological contact is a permeability boundary. This section intersects the key block of the entire structure. There are high stress concentrations at the base of the unstable mass, on J4 extremities and on vertical shear zones parallel to the section. Periods of high water pressure have promote fracturing within these rock masses.

northeast of Randa; estimated magnitude: 6.1) and 1855 (epicentral location: Visp-Stalden, 10-20 km north of Randa; estimated magnitude: 6.4) (Fig. 1) (data: Ecos, Swiss Seismological Service, http://seismo.ethz.ch). Historical chronicles confirm that many rockfalls occurred throughout the Mattertal during and immediately after the 1855 earthquake (Lenoir, 1949). Triggering effects of such energetic seismic waves on rock bridges are certain. Vertical accelerations seem to promote the formation of composite gliding surfaces by connecting adjacent joints; for example, vertical acceleration could have weakened the future failure surface for the 9 May rockslide.

\subsection{Groundwater circulation}

Groundwater circulation within the network of joints can act as a triggering mechanism by effects of chemical alteration and water pressure. The proposed hydrogeological model is schematic, because precise hydrogeological data are sparse (Girard, 1998; Girod, 1999). The slope failures were located on a ridge separating two drained flanks. The small infiltra- 
tion area for groundwater supplying the network of joints in the Randa cliff extends in elevation from $1900 \mathrm{~m}$ to $2400 \mathrm{~m}$. Opening of fractures by sagging processes around the old scarp surface promoted high infiltration rate during snowmelt periods (see Sect. 5.2). Temporary springs could clearly be identified issuing from the rock face, (Figs. 2b and 8); these springs could be correlated to the features of the 3-D model. Within the unstable orthogneiss rock (Fig. 6), the water drained mainly along the J6 and J2 subvertical joints, and also along the southeast-dipping J4 joints, as revealed by the oxidation spots on the surface of the present scarp. The gently dipping contact between the paragneisses and orthogneiss acted as a permeability boundary. The basal J3 fault constituted an aquiclude, and gave rise to the main spring, located at the intersection of $\mathrm{J} 2$ draining fractures.

Within the orthogneiss fractures, water circulation promoted mineralogical alteration, as noted by observations in the Mattervispa River bypass tunnel (Figs. 1 and 6) (Girod, 1999). Some of the draining faults were filled with gouge affected by in situ alteration and precipitation of smectite minerals. A very low angle of internal friction can therefore be postulated for the sliding surfaces of the 18 April rockslide, especially for the basal J3 fault.

The other triggering factor due to groundwater circulation consists of the hydraulic fracturing. Unfortunately, quantitative data on the intensity, distribution, and evolution with time of the water pressure within the fractured rock mass are lacking (see Sect. 5.2 for discussion).

\section{Post-glacial evolution of slope stability}

The processes that finally led to the 1991 Randa rockslides acted since retreat of the glaciers. Long periods of postglacial quiescence were disturbed by two or more episodes of instability.

\subsection{Pre-20th century episodes of instability}

The old scarp in the paragneisses and the debris cone mentioned in Sect. 2.5 are of unknown age. This scarp corresponds to one or more rockslide(s), with a total volume estimated at 10 mio $\mathrm{m}^{3}$. It is unclear, whether or not a part of the underlying orthogneiss was also involved in a process in which the foot of the wall was removed ("loss of foot" process). These events changed the topography, causing a weakening of the paragneisses ridge and promoting groundwater infiltration within the orthogneiss that forms the foot of this ridge (Fig. 3).

The top of this old scarp later became unstable, and is still collapsing with a slow sagging mechanism. A dismembered mass of paragneisses, rock blocks and gravels-size debris lay on the former gliding surface of the rockslide, between $1800 \mathrm{~m}$ and $2050 \mathrm{~m}$ elevation (identified as a rock avalanche deposit on Bearth's geological map, 1964). The total volume of the mass has been estimated at $5 \mathrm{mio} \mathrm{m}^{3}$, and its thickness as much as $40 \mathrm{~m}$.

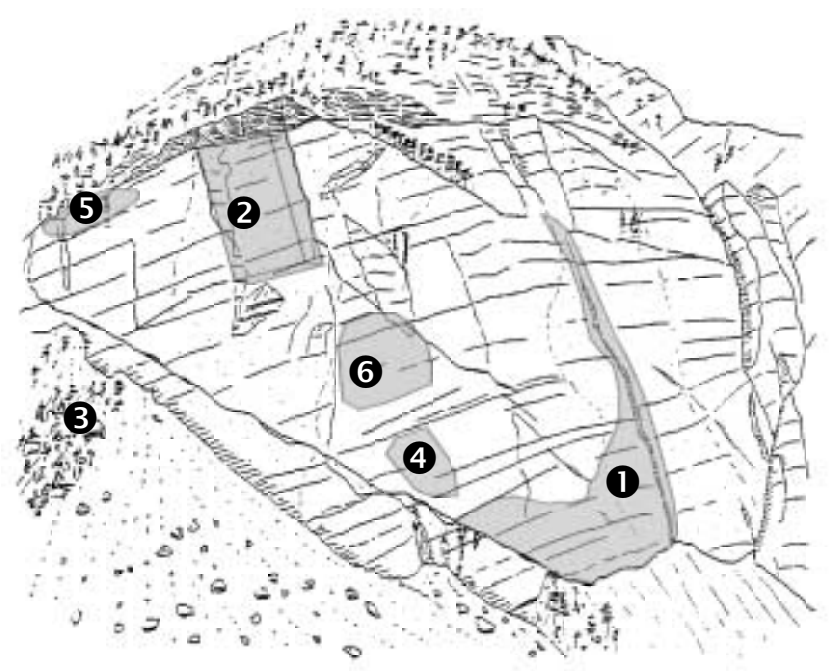

Fig. 7. Location of precursory events within the orthogneiss rock face (1970-1991), (modified from Schindler et al., 1993). A 20year period of increasing rockfall activity culminated on the day before the 18 April rockslide with the explosion-like failure of rock slabs and sprays of water under pressure above the main spring. 1) 1970-1991. 2) 1979. 3) Forest destruction: 1979-1991. 4) 17 April 1991. 5-6) 18 April, before the final failure.

Until the beginning of the $20^{\text {th }}$ century, on the oldest available photographs, except for these superficial phenomena, only a few signs of activity within the perimeter of the future 1991 rockslide are detectable. At the middle of the nearvertical Randa orthogneiss cliff, a scarp resulting from the failure of an overhang involving roughly $10000 \mathrm{~m}^{3}$ of rock looked relatively fresh in a photography from 1910. At that time, the forest at the foot of the cliff appeared to be moderately impacted by rockfall. On all photographs, the two main single persistent discontinuities can be observed: the $\mathrm{J} 3$ basal fault that cut obliquely the base of the wall (Fig. 2a-b) and the J6' lateral border fracture.

\subsection{Kinematics of the $20^{\text {th }}$ century slope failure}

\section{9-1991 precursory events}

During the middle of the 20th century, increasing rockfall activity affected the northern part of the orthogneiss rock face (Figs. 2 and 7). Further acceleration of activity occurred in 1979 , with the fall of some tens of thousands of cubic meters of rocks from the upper middle part of the cliff. Rockfall activity continued, spreading to the entire cliff, with particular intensity on the northern part. As a result, the forest beneath was almost totally destroyed before the 1991 rockslides occurred.

\section{Stress and strain indicators, dynamic model}

The deformations that occurred on the orthogneiss rock face before the spring of 1991 are significant for the stress and strain processes acting within the unstable rock mass (Fig. 8). On one hand, the $\mathrm{J} 2$ persistent fractures bordering the pris- 


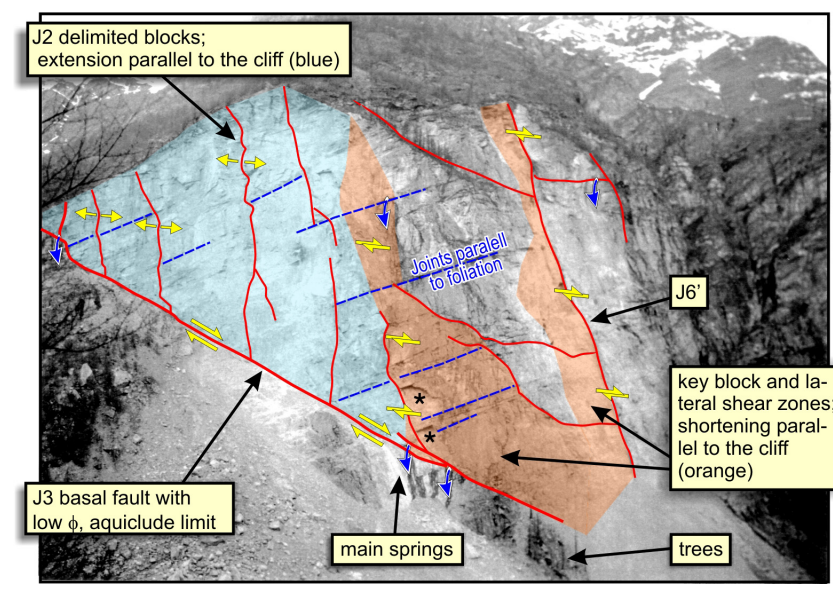

Fig. 8. Photograph of the orthogneiss wall on the evening before the 18 April rockslide. The apparent structures, springs, and zones of ongoing fracturing are interpreted in terms of strain. The key block at the lower right part of the unstable mass (orange coloured) underwent shortening and expulsion along two vertical shear zones. Explosion-like failure of rock slabs had already occurred in the southern shear zone, above the main springs (stars). The prismatic blocks at the upper left part of the unstable mass (blue coloured) underwent extension parallel to the direction of the cliff, with opening of the $\mathrm{J} 2$ discontinuities. The springs are situated mainly along the intersection between the draining $\mathrm{J} 2$ fractures and the sealed J3 basal fault (photograph: Y. Dupertuis, 1991).

matic rock blocks of the northern part of the unstable mass were open and clearly suffered extension. On the other hand, compression prevailed in the lower northern part, above the $\mathrm{J} 3$ persistent fault, as indicated by signs of fracturing of rock slabs. A shear zone along the J6' discontinuity also suffered fracturing processes.

These observations, together with the 3-D geometrical model, suggest the following dynamic interpretation. Before the 18 April loss of equilibrium, the wide basal $\mathrm{J} 3$ fracture had no cohesive resistance and only a weak angle of friction. Prismatic blocks of rock divided by the $\mathrm{J} 2$ fractures underwent extension parallel to the axis of the Mattertal, either because of the stress exerted by the above disrupted sagging masses of paragneisses or because of the shortening of the northern part of the unstable rock mass. The northern part of the rock mass clearly acted as a key block, affected by high compressive stress (Fig. 8). Deformation was concentrated at the base of the cliff, just above the J3 basal fracture, and on both sides of the key block: on the J6' lateral ramp on the northern side and on a J2 vertically oriented shear zone on the southern side, delineated by springs. These deformations indicated a progressive expulsion of the key block toward the valley.

\section{Ultimate triggering event}

Only micro-earthquakes $(M w<2)$ were recorded for the Randa area during the days before the 18 April 1991, rockslide (Schindler et al., 1993). As these low-energy seismic events are frequent in this area, seismic activity is not con- sidered to have been the ultimate triggering event.

A heavy snowmelt period occurred in the area a few days before the 18 April rockslide. As all temporary springs were active on the entire rock wall, water pressure undoubtedly was at its annual maximum within the fissure system, and probably promoted hydraulically assisted fracturing. However, some questions remain without answer: Was the high water pressure of this time period an exceptional triggering event that released the rockslide? Did the intense snow-melt period, enhanced by warm wind ("foehn") produce a higher water pressure than usual? Did the sudden freezing period (temperatures as low as $-7^{\circ} \mathrm{C}$ ) occurring the day before the rockslide have an unknown triggering effect? Or was this period an ordinary annual triggering event that acted on a fractured unstable rock mass the strength of which was progressively reduced to point of failure?

The fracturing effects produced by water pressures had been observed since the day before the 18 April rockslide (Schindler et al., 1993) (Fig. 8). Three rock slabs thousands of $\mathrm{m}^{3}$ in volume were ejected in turn above the zone of the main springs, along a vertical trend corresponding to the southern sheared limit of the key block. These explosion-like fracturing events were followed by water sprays, suggesting an hydraulic fracturing component. The fall of the upper rock slab occurred 10 min before expulsion of the key block and final collapse of the valley wall.

\section{April 1991, rockslide}

Observations of the 18 April 1991, rockslide phases, reported by Schindler et al. (1993), were limited because of the cloud of dust. However, it has been established that the key block of the lower northern part of the valley wall broke loose first, followed by the overlying rock blocks (Fig. 9a-b). The multistage process required half an hour for roughly $10 \mathrm{mio} \mathrm{m}^{3}$ to fail. The main mechanism of mobilization probably was sliding along the $\mathrm{J} 4$ and $\mathrm{J} 3$ discontinuities, with shearing along the J6' single plane and detachment on J6 fractures. Breaking up of the rock also was facilitated by $\mathrm{J} 2$ discontinuities and joints parallel to the schistosity.

The southern large prismatic blocks temporarily remained upright without the support of a buttress. They then failed in turn during an ensuing one-hour period (Fig. 9c-e). Sliding of the rock prisms along the basal J3 discontinuity and "foot failure" seem to have been the two most efficient mechanisms for this estimated 12 mio $^{3}$ part of the rockslide. Volumes of paragneisses were also removed from the crown of the slide, including part of the ancient sagging mass, which caused an increase in the volume of dust. A later minor event occurred on 22 April.

If the whole $22-$ mio- $\mathrm{m}^{3}$ volume of the 18 April rockslide would have collapsed instantaneously, a rock-avalanche extending several kilometers downstream would certainly be produced. Because individual rock blocks of several mio $\mathrm{m}^{3}$ fell down successively and presumably because of the roughness of the previous debris cone, the final deposit was a new huge steep debris cone. The mechanism of deposition was also influenced by the rheological properties of the very competent orthogneiss. 


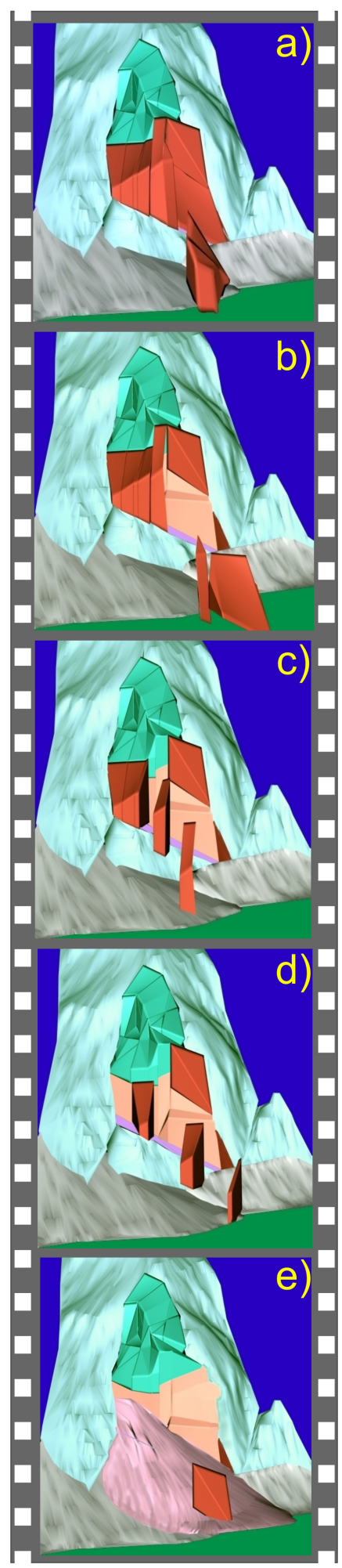

Fig. 9. Time-dependent 3-D model of the 18 April 1991, Randa rockslide. (a) 18 April, 06:30 am to 07:00 am: expulsion and breaking off of the key block (volume approximately $5 \mathrm{mio} \mathrm{m}^{3}$ ). (b) Sliding of the superposed blocks on J4 discontinuities (volume approximately 5 mio $^{3}$ ). (c)-(e) 07:00 am to 10:00 am: progressive failure of the southern prismatic blocks, sliding on the J3 basal fracture (violet) (volume approximately $10 \mathrm{mio}^{3}$ ), and finally failure of the uppermost right corner (e, volume approximately $0.5 \mathrm{mio} \mathrm{m}^{3}$ ).

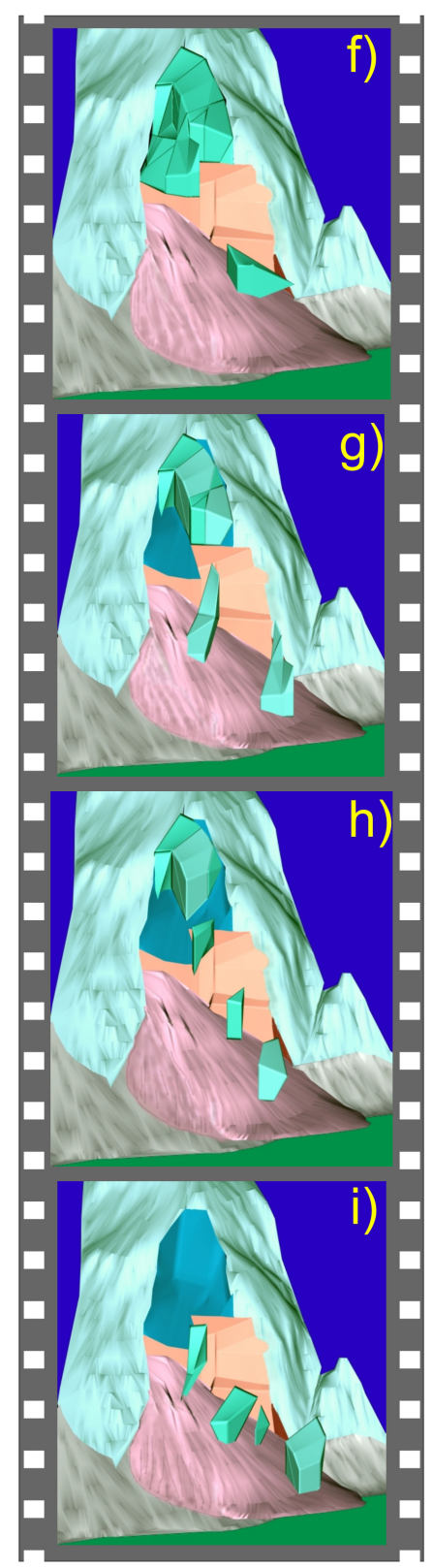

Fig. 10. Time-dependent 3-D model of the 9 May 1991, Randa rockslide. (f)-(i) 9 May, 06:30 pm to 09:00 pm: progressive failure of the broken up paragneisses mass (volume approximately $7 \mathrm{mio}^{3}$ ) on a sliding surface (f) $-(\mathrm{g})$ and detachment from the archshaped crown (h)-(i).

These rocks bear medium to high strength (80-180 MPa uniaxial compressive strength; Girod, 1999), that led to a very heterogeneous granulometry of the debris, with a large amount of large blocks (up to one thousand $\mathrm{m}^{3}$ in volume). The location of the accumulation of debris indicates a main trajectory toward the northeast, in accordance with the sliding direction of the J3-J4 wedge. Schindler et al. (1993) calculated a total buckling coefficient for 18 April and 9 May rockslides of 1.190 to 1.215 ; they infer that voids due to 
aperture of joints within the unstable mass before collapse reached 7 to $15 \%$ in volume. However, the lack of precise volume estimations of the 18 April rockslide, debris, dust, and reactivated sagging masses and scree, as well as the lack of a granulometric analysis of the debris cone (Couture et al., 1996) makes these values questionable. The final topographic change induced by the 18 April rockslide consisted of a near-vertical cut perpendicular to the direction of the ridge (Fig. 2c). The scarp exposed the lithological contact between the orthogneiss and the paragneisses, dipping gently southward. The paragneisses formed a triangle outcropping at the upper third of the rock face. At some locations, springs flowed from the contact, denoting the contrast in permeability between the two lithologies.

We made a qualitative estimate of the roughness of the detachment and sliding surfaces exposed at the scarp (Fig. 5). If this criterion can be correlated with the importance of the fracturing of rock bridges between pre-existing fractures, it clearly illustrates that the northern side of the unstable rock mass may have acted as a key block.

\section{May 1991, rockslide}

A warning system was installed the day after the 18 April rockslide (Ischi et al., 1991; Rouiller, 1992; Götz and Zimmermann, 1993; Schindler et al., 1993). Fracture openings and seismic measurements provided very useful results in anticipating the 9 May phase of the rockslides.

Once again, water-pressure-assisted fracturing could have acted as the ultimate triggering effect, as the 9 May rockslide was preceded by explosion-like activity and release of water under pressure above the pre-existing springs. The ongoing failure sequence took more time (about $3 \mathrm{~h}$ ), and proceeded with smaller volumes than those of 18 April (Fig. 10f-i). The dismembering activity moved from the northern part of the future scarp, toward its center against the ridge, and at last towards the arch-shaped head of the scarp. The Randa orthogneiss was not affected by this second phase of the rockslide. The debris spread on the pre-existing scree, mainly towards east-southeast.

This rockslide event consisted of a retrogressive reequilibrium of the slope. The ongoing global mechanism was fairly simple. The ridge formed by the paragneisses was truncated along a surface (135/40), whose trace on the 18 April scarp roughly coincided with the orthogneiss-paragneisses limit. This sliding surface, now hidden by scree, consisted of the J4 persistent fractures probably connected together by $\mathrm{J} 2$, J5 and $\mathrm{J} 6$ discontinuities. The detailed mechanisms of the successive rockfalls were more complex because small volumes were involved, as a result of the highly fractured rock mass including as many as ten sets of discontinuities. This high density of fractures resulted in a an arch-shaped geometry of the retrogressive scarp.

\section{Present-day movement}

The present-day monitoring of the open fractures above the scarp and the geodetic survey, show slow ongoing deformation, with a maximum speed of $1-2 \mathrm{~cm}$ per year (CREALP database). A new 2.5-mio- $\mathrm{m}^{3}$ unstable rock mass (Ischi et al., 1991; Eberhardt et al., 2001) indicates the existence of a

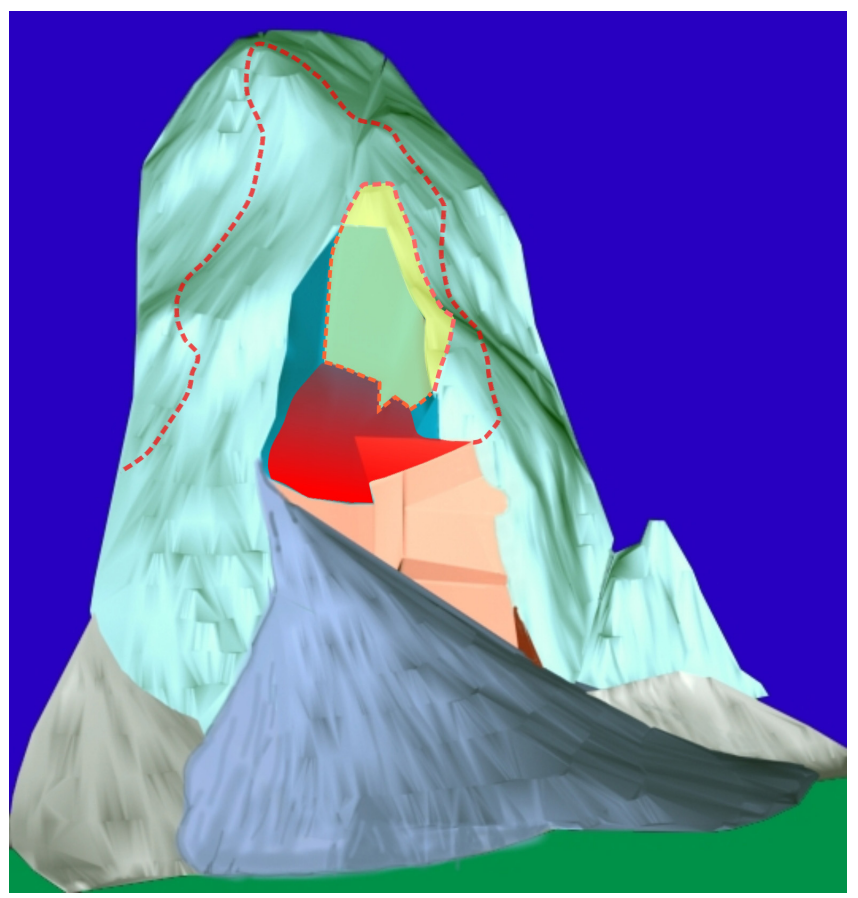

Fig. 11. Present day instability (yellow contouring) at Randa. The sliding surface of the 9 May rockslide (red) is probably involved in today's mechanism of slow sliding. This surface has been extrapolated to intersect the ground surface (red contouring), delimiting the long-term retrogressive potential of the unstable mass.

retrogressive erosion process by propagation of the slope failure mechanisme along the ridge of paragneisses. The geodetic displacement field is compatible with a sliding mechanism in the dip direction of the pseudo-J4 surface, which acted during the 9 May rockslide (Fig. 11).

\section{Synthesis of the kinematics of the Randa rockslides}

If our geometric, dynamic, and kinematic interpretations of the Randa rockslides are correct, then the characteristics and the evolution of this peculiar unstable area can be listed as follows:

- Glacial erosion created here a 500-m-high, near-vertical cliff, within a very competent lithology constituted by the Randa orthogneiss.

- A single, more than 500-m-long, persistent fault cut the orthogneiss rock face. Its dip $\left(30^{\circ}\right)$ and dip direction $\left(030^{\circ}\right)$ nearly parallel to the axis of the Mattertal $\left(015^{\circ}\right)$, the low angle of internal friction along its surface, and the presence of a continuous detachment system, all could help generate a rockslide. However, the sliding mechanism was forestalled by the existence of numerous rock bridges that separated the discontinuities on the northern side of the unstable mass; these rock bridges delimited a rock volume that acted as a key block. 
- Regional macroseismic activity and weathering of the orthogneiss along the fissure network slowly modified the mechanical properties of the sliding surfaces, and broke up the rock bridges. The progressive lowering of the friction angle of the sliding surfaces increased the stress acting on the key block.

- The water infiltration capacity of the paragneisses extending above the unstable mass was increased by several "superficial" failures (rockslides, sagging, etc.).

- The weathering of the gouge material in the basal fault produced in situ formation of smectites. As a consequence, the fault progressively acted as an impervious limit to groundwater flow, leading to an annual increase in the hydraulic head of the aquifer during the snowmelt periods. Repeated fracturing occurred along the shear zones that bordered the key block.

- The final triggering event for the 1991 rockslides was the high water table of that spring. It has not been established if this was an exceptional snow-melt event, considering the instantaneous water supply (effect of a warm wind). On 18 April, the high water table led to an explosion-like fracturing of rocks and the expulsion of the key block, followed by sliding and "foot failure" of the other rocks blocks, involving an overall volume of roughly $22 \mathrm{mio} \mathrm{m}^{3}$.

- The re-equilibrium process of the slope began 20 days later on the overlying paragneisses. The 9 May rockslide (volume approximately $7 \mathrm{mio} \mathrm{m}^{3}$ ) slid on a $40^{\circ}$ dipping surface, cutting the ridge from the top of the stable massive orthogneiss upslope. This event may be considered as the first expression of the current retrogressive erosional process.

The duration of this chronological sketch can be synthesized as follows: (1) the seismic- and weathering-assisted degradation process took roughly 15000 years; (2) the final mechanical weakening of the key block: roughly 20 years; (3) the ultimate fracturing and expulsion of this key block: 2 days; and (4) the collapse of the complex instability: $3 \mathrm{~h}$. Re-equilibrium of the slope after the 18 April event began 20 days later, and will probably last for hundreds of years.

\section{What can be derived to detect similar instabilities?}

The Randa rockslides bear its own lithology and geometrical characteristics. Very similar cases can be found downstream on the western wall of the Mattertal (Rouiller et al., 1998), or in similar alpine contexts with intrusive bodies surrounded by paragneisses, such as the Val Pola landslide (Costa, 1991). But considering its complex structural pattern, Randa can hardly be considered as a "common model". However, three main characteristics of the Randa unstable area can be of interest in the detection of further cases of instability in very large rock masses:
- In the European Alps, most of the very unfavorable structural configurations were probably activated soon after the retreat of the glaciers. However, a very persistent single fault of wide extension, cutting a competent lithology with a "unfavorable" orientation can easily form, together with a network of joints, a "latent" instability of large volume. A long period of seismic activity and weathering can precede the rockslide event.

- Unfavorable structural configurations frequently are locked by a key block of rock. Chemical, seismic, and mechanical processes can weaken these stressed rock masses to below the strength thresholds required for stability. The damage caused by the seismic and weathering processes are often subtle and cannot be detected. On the contrary, progressive fracturing along the shear zones, as well as the crushing of rocks within highly compressed zones, produce a high frequency of rockfall activity (resulting in presence of active scree deposits, damage to forests and infrastructures, etc.), which is useful in the detection of unstable areas;

- The role of water pressure as a theoretical triggering mechanism is often mentioned (Erismann and Abele, 2001), but poorly documented. In the case of the Randa rockslides, the impervious boundary formed by the wide basal fault allowed high water pressure to be concentrated around the key block, as shown by the spring system. Such hydrogeological behavior of faults can result directly from the existence of fine-grained fault gouge or from weathering of this fault gouge (Girod, 1999), which can lead both to decrease of the friction angle and to filling up of the void space along the fault.

Lessons of the Randa rockslides for the detection of future instabilities can roughly be summarized as: "presence of a large structural unfavorable configuration + increase in rockfall activity + highly variable water table $=$ danger". The temporal aspect of the forewarning signs must be emphasized: the detectable high rockfall activity associated with fracturing in the vicinity of the key block lasted roughly 20 years. This is an encouraging example for risk management, but is not of statistical significance.

In addition, the tentative reconstruction of the kinematics of the rockslide shows that this type of instability involving a large rock mass volume with a complex geometrical pattern cannot be studied, whether "a posteriori" or "a priori", without a 3-D analysis.

Acknowledgements. We thank Prof. D. M. Cruden (University of Alberta) and Dr. F. Girod (University of Lausanne) for their useful discussions of our paper. We also thank the two reviewers R. L. Schuster and G. F. Wieczorek (U.S. Geological Survey). Their comments helped greatly to improve the manuscript. Part of this research has been supported by the Swiss National Science Foundation (grant number 2100-50781.97). 


\section{References}

Bearth, P.: Geologischer Atlas der Schweiz, Blatt $\mathrm{N}^{\circ} 1328$ Randa mit Erklärungen, Schweizerische Geologische Kommission, 1964.

Costa, J. E.: Nature, mechanics, and mitigation of the Val Pola Landslide, Valtellina, Italy, 1987-1988, Z. Geomorph. N. F., 35/1, 15-38, 1991.

Couture, R., Locat, J., Hadjigeorgiou, J., Evans, S. G., and Antoine, P.: Développement d'une technique de caractérisation des débris d'écroulements rocheux, in: Landslides, Proceedings of the 7th International Symposium on Landslides, edited by Senneset, K., Trondheim, Balkema, Rotterdam, 2, 1177-1182, 1996.

Discreet: 3-DStudioMaxTM 5 software

Eberhardt, E., Willenberg, H., Loew, S., and Maurer, H.: Active rockslides in Switzerland - Understanding mechanisms and processes, in: International Conference on Landslides Causes, Impacts and Countermeasures, edited by Kühne, M., Einstein, H. H., Krauter, E., Klapperich, H. and Pöttler, R., 1721 June 2001, Davos, Switzerland, VGE, Essen, 25-34, 2001.

Erismann, T. and Abele, G.: Dynamics of rockslides and rockfalls, Springer Verlag, Berlin, 316, 2001.

Ferrero, A. M., Segalini, A., Giani, G. P., and Marro, C.: Studi geomeccanici ed idrogeologici applicati alla frana di Randa, in: CNR-IRPI Convegno Internazionale "La prevenzione delle catastrofi idrogeologiche: il contributo della ricerca scientifica", edited by Torino, Alba, 145-154, 1996.

Girard, N.: Etude de la perméabilité et de la porosité du gneiss de Randa, DEA Thesis, Université de Poitiers, Poitiers, 1998.

Girod, F. and Thélin, P.: Weathering of granitic rocks in the Alps: preliminary results from orthogneiss associated with the Randa rockfall (Matter-Valley, Valais, Switzerland), Schweiz. Mineral. Petrogr. Mitt., 78, 179-184, 1998.

Girod, F.: Altération météorique de roche granitique en milieu alpin: le cas de l'orthogneiss associé à l'éboulement de Randa (Mattertal, Valais, Suisse). PhD Thesis, Université de Lausanne, Lausanne, 207, 1999.

Goodman, R. E. and Shi, G.-H.: Block theory and its application to rock engineering, Prentice-Hall International Series in Civil Engineering and Engineering Mechanics, Prentice-Hall, London, $338,1985$.

Götz, A. and Zimmermann, M.: The 1991 rock slides in Randa: causes and consequences, Landslide News, 7/3, 22-25, 1993.

Ischi, H., Keusen, H.-R., and Scheller, E.: Bergsturz Grossgufer vom April/Mai 1991, Zusammenfassender Berichte über die Aktivität der Geotest A.G., unpublished report number 91126, Geotest, Martigny, 20 and annexes, 1991.

Lenoir, D.: Récit du tremblement de terre du Valais (25 juillet 1855), Bull. Murithienne, 63, 25-28, 1949.

Naturforschende Gesellschaft Oberwallis: Der Bergsturz von Randa 1991, eine Dokumentation. Mitteilung der Naturforschende Gesellschaft Oberwallis, 2. Druckerei Tscherrig, Brig, 180, 1995.

Noverraz, F. and Bonnard, C.: L'écroulement rocheux de Randa, près de Zermatt, in: Landslides, Proceedings of the 6th International Symposium, Christchurch, edited by Bell, D. H., Balkema, Rotterdam, 1, 165-170, 1992.

Pirocchi, A.: Laghi di sbarramento per frana nelle alpi: tipologia e evoluzione, Tesi di dottorato, Università di Pavia, Pavia, 155, 1992.

Rouiller, J.-D.: L'éboulement de Randa, Route et Trafic, 92/5, 373 376, 1992.

Rouiller, J.-D., Jaboyedoff, M., Marro, C., Philippossian, F., and Mamin, M.: Pentes instables dans le Pennique valaisan. Matterock: une méthodologie d'auscultation des falaises et de détection des éboulements majeurs potentiels. Rapport final du PNR31. VDF, Zürich, 239, 1998.

Saegesser, R. and Mayer-Rosa, D.: Erdbebengefährdung in der Schweiz, Schweiz. Bautzg. 87/7, 3-18, 1978.

Schindler, C., Cuenod, Y., Eisenlohr, T., and Joris, C.-L.: Die Ereignisse vom 18 April und 9 Mai 1991 bei Randa (VS) - ein atypischer Bergsturz in Raten, Eclogae geol. Helv., 86/3, 643665, 1993.

Thélin, P.: Nature originelle des gneiss oeillés de Randa, Bull. du Laboratoire de Géologie de l'Université de Lausanne, 290, Lausanne, 1987.

von Bidder, H.: Bergsturz in Randa: Bericht über den militarischen Einsatz und die Zusammenarbeit mit den zivilen Behörden und Unternehmungen, 2, Bundesamt für Luftschutztruppen, Bern, 41, 1991.

Wagner, A.: Bergsturz Grossgufer Randa, étude structurale et géomécanique, Unpublished report number 91.35, CRSFA, Sion, 16 and annexes, 1991.

Wagner, J.-J., Frischknecht, C. Rosset, P., Sartori, M., Schindler, C., Beer, C., Mayer-Rosa, D., Rüttener, E., and Smit, P.: Contribution au zonage sismique dans la vallée du Rhône, entre Sion et Brigue, Rapports géologiques, 25, Service hydrologique et géologique national, Bern, 133, 2000. 